\title{
About the Need to Adjust the Regulations Regarding the Form of Will to the Modern Requirements
}

\author{
Mariusz Załucki \\ Institute of Private Law, Krakow University, Poland
}

Doi: 10.19044/elp.v6no2a1

URL:http://dx.doi.org/10.19044/elp.v6no2a1

\begin{abstract}
A will is a traditional instrument for disposing of property in the event of death. Model solutions of this kind date back to Roman times, which survived thousands of years and are still, in a slightly modified form, in the legal regulations of individual states. However, recent years have been a period of intensive development of new technologies. Against this background, the question arises as to whether or not instruments linked to new technologies can be used by testators to dispose of their property in the event of death, and whether or not there is a need to do so, and whether inheritance law based on Roman tradition fulfils its role. This has become the subject of research in which the author tries to demonstrate the need to adapt the testamentary formalities to the requirements of modern times. The aim of the study is to present the challenges posed by technological possibilities in the area of wills and to consider whether the legislators should take into account technological changes and related social needs in the inheritance law. In this connection, the author describes the issues that took place in selected countries which concerned the preparation of wills using technological benefits and, contrary to the current requirements as to the form of preparation of wills, presents how individual legislators coped with the emerging problems in this area. In his dogmatic and comparative legal analysis, he tries to answer the question of the need to adapt the formal requirements accompanying the drafting of wills to the technological requirements.
\end{abstract}

Keywords: Wills, formalities, succession, inheritance.

\section{Introduction}

A will as a disposition of property upon death is now the main alternative to statutory succession ${ }^{1}$. Although the rules applicable to drawing

1 The article is part of a project funded by the National Science Centre, Decision No DEC2013/11/B/HS5/03792. More on the results of the research is published in a monograph: Videotestament. Prawo spadkowe wobec nowych technologii, Warszawa 2018. 
up a will are frequently questioned ${ }^{2}$, the reality shows that dispositions by way of a will are the most popular tool in the particular legal systems used to regulate the legal relationships after the death of the testator ${ }^{3}$. This refers not only to the future of the property of the testator mortis causa but also broader understood social relationships among the persons closest to the testator. The succession law instruments, which have been created with years, may be assessed in a comprehensive context, not only as ones applicable to the future of the succession property. Such structure is important because according to some social assessments the possibility of drawing up a will has a much wider reach than it could be thought prima facie. This refers also to such actual situations in which the intent of the testator is to dispose of their property upon death, which - due to the reasons mostly attributed to the testator, just to mention the lack of adequate knowledge - simply becomes ineffective. In the times of great engagement of the potential testators in the world of new technologies, which is undoubtedly the case currently, one of the issues which - as it may be conceived - requires a non-standard perception is the statutory framework of mortis causa legal actions. Can the extraordinary nature of the current times may be closed within the frames of seemingly ordinary legal structures, which have basically been known already at the time of the Roman rule $^{4}$ ? Whether in the succession law there is no alternative for the regulations applicable to the form of a will and testators must avail of the traditional instruments? This article is an attempt of proving that it is not the case and that legislative changes are needed in order to follow the technological progress ${ }^{5}$.

\section{Last will expression}

Throughout the years the practice of the succession law in the particular legal systems has been differently reacting to the problems related to the form of a will. The testators have been expressing their last will in various manners. Despite the fact that the regulations applicable to the form of a will in the specific law systems usually provided for the duty to draw up a will in a strictly formal way, particularly in writing, or before a person

2 See, for example, M. Zatucki, Forma testamentu w perspektywie rekodyfikacji polskiego prawa spadkowego. Czas na rewolucję?, Państwo i Prawo 2017, issue 3, p. 36 et seq.

3 R. Pound, The Role of the Will in Law, Harvard Law Review 1954, issue 1, p. 1 et seq.; H.E. Nass, We Can't Stop Loving You, Trusts \& Estates 2005, issue 8, s. 64; R. Zimmermann, Testamentsformen: »Willkür« oder Ausdruck einer Rechtskultur?, Rabels Zeitschrift für ausländisches und internationales Privatrecht 2012, p. 473 et seq.

4 R. Świrgoń-Skok, Swoboda dysponowania majątkiem na wypadek śmierci w ujęciu historycznoprawnym, [in:] Rozprawy cywilistyczne. Ksiega pamiatkowa dedykowana Profesorowi Edwardowi Drozdowi, eds. M. Pecyna, J. Pisuliński, M. Podrecka, Warszawa 2013, p. 527 et seq.

5 See for more details: M. Zatucki, Videotestament. Prawo spadkowe wobec nowych technologii, Warszawa 2018, passim. 
authorised to take the will, sometimes in the presence of witnesses, they not always reflected the actual needs of the testators. The testators were not always aware of the requirements set out by the legal regulations for the last will declarations. Therefore, except for holographic or allographic wills, which were the forms of will the most frequently accepted by the laws of the particular countries, there were cases in practice when wills were prepared otherwise, without regard for the regulations applicable to the form. There have been some cases in which an attempt have been made to use for the disposition of property upon death of instruments which, at the moment of making the will, were a new technological element adequate to the needs of everyday life. Trying to declare their last will in a manner adequate to their own needs, the testators were using technical tools known to them from everyday life and wanted to use them also for the needs mortis causa. This brought about various effects, as confirmed with the following examples of failure on the part of the testators to follow the traditional legal structures, by which they wanted to dispose of their property upon death in a manner adequate to the their contemporary times, which not necessarily brought about the effect conceived by them.

\section{Technical inventions and last will}

In that regard we may commence from stating the fact that already in the 1930s there were practical attempts to use the technical inventions for legal succession purposes. One of the cases described in literature is the judgement of the Supreme Court of the Third Reich of 1935 applicable to a will recorded on a gramophone ${ }^{6}$. It was considered that although the authenticity of the will declared in that way raises no doubts, in accordance with the binding BGB provisions the will may not be declared with the use other media except for one's own handwriting, and only the legislator could decide otherwise. Despite the attempt to qualify such will as personal one, it was declared invalid, which was further slightly criticised by the doctrine, namely by indication that the requirement of one's own handwriting may not be treated literally, and a voice recording may be practically treated as one fulfilling the requirement of self preparing ${ }^{7}$.

Similar conclusions were drawn nearly fifty years later, in 1980, by the Supreme Court of the American State of California. In a matter which actually did not refer to the succession law, the court decided that recording on an audio cassette may be treated equal with handwriting ${ }^{8}$. It is important because three

6 Reichsgericht judgement of 18 July 1935, Deutsche Juristenzeitung 1935, p. 78.

7 See G. Ponath, Die Beschränkungen der Testierfreiheit durch das Testamentsrecht, Frankfurt-Mannheim 2006, s. 251.

8 Supreme Court of California judgement of 23 October 1980, Darley v. Ward, http://law.justa.com/. 
years later, in 1983, before the Supreme Court of the American State of Wyoming a case was heard as to whether the will of the testator recorded on an audio cassette may be valid ${ }^{9}$, and the court referred to the decision of the Court of California. As regards the facts of the case of 1983, it was decided that the testator left the audio cassette in a closed envelope with an instruction to open it only if he died. And on the cassette he recorded the instructions applicable after his death. In accordance with the then binding regulations in the State of Wyoming, accordingly to the contents of § 2-6-112 of the Wills Statute 1977, the will for its validity required a special (written) form, prepared with the testator's own handwriting or typewriting, and the participation of witnesses. Further, the provisions of $\S 2-6-113$ of the same Statute allowed the acceptance of a will to be valid even if prepared without witnesses, providing that it was handwritten by the testator and signed. In this case, one of the parties referred to the aforementioned judgement o 1980, claiming that the will recorded on an audio cassette fulfils the requirements for self-prepared wills, and that the voice recording on a cassette fulfils the same function in the times of an advanced technology as handwriting had fulfilled in the times of preparing the legal requirement for hand-written wills and should, therefore, be treated equal with handwriting. The argument was not supported by the court handling that succession case, as the judge indicated that the decision on the possible use of such recordings for the legal succession purposes might only be made by the legislator and not the court, which could not step outside of the binding law or create new forms of wills. The said will was classified as an oral will, and such form was not acceptable at the moment of the judgement in the State of Wyoming, and the right to the inherited property was refused on that basis. The judgement also met some critique at that time, as it was suggested that such dispositions upon death should be considered valid, equally as the possible wills recorded with the use of audio-video methods, since they may provide reliable evidence of the intent of the testator ${ }^{10}$.

A similar situation appeared in 1996 in one of the succession cases considered in Canada (the Province of Quebec). In that case the testator left behind an envelope with a disc inside, on which he had personally written that it was his last will and had signed it. The disc comprised an electronic file with the dispositions mortis causa, reflecting the will of the testator. Despite the fact that the disposition did not comply with the formal requirements of the provisions of the local law, as the Civil Code of Quebec required a notarial form, a handwriting or attendance of witnesses (Article 712), the probate court decided that such disposition is valid, by applying the rule derived from the

9 Supreme Court of Wyoming judgement of 12 January 1983, Estate of Robert G. Reed, http://law.justa.com/.

10 Cf. J.C. Smiley, The Enforcement of Unwritten Wills - Estate of Reed, Land $\S$ Water Law Review 1985, No. 20, p. 279 et seq. 
substantial compliance doctrine provided in Article 714 of the Civil Code of Quebec and accepted the inheritance based thereon11. Already then it was signalled that in the contemporary times a will should not be treated as a strict formal act, particularly because the development of technology forces the compliance with the regulations applicable to the form of a will rather as $a d$ probationem than ad solemnitatem. Abiding by a particular form is to be first of all the evidence of drawing up the last will and is not to impose the structure of the will12. It was also noted that the times of electronic communication may bring about intensive changes in the legal regulations in that regard, in order to enable recording the human memory in the memory of a computer 13.

In another case held in the Republic of South Africa in 2000, the testator had left a note with his forename, surname an identification number, and information that his will may be found on the hard disc of his computer in a specific directory 14 . The laws of the RSA required a written form for a will to be valid, plus the signature of the testator and the attendance of witnesses see Article 2.1.a) of the Wills Act 1953. Despite such requirements, the court decided that thwarting of the last will of the testator by way of the noncompliance by the person with the technical formalities must be prevented, indicating that in the interpretation of the binding regulations the reality of the technological world in which the society is living must be taken into account15. In the doctrine a trend to liberalise the regulations regarding the form was indicated 16 as well as the need to introduce legislative changes considering the fact that people are going to use electronic tools to dispose of their property mortis causa, whereas the law should not prevent the use of technological achievements 17.

The similar actual situation was considered in Australia approximately at the same time. In the judgement of 14 March 2002, the Supreme Court of the State of Victoria considered the validity of disposition upon death made by the testator in a file recorded on the hard disc of a computer. The persons questioned as witnesses confirmed that the testator had informed them about

11 Quebec Supreme Court judgement of 3 Decemner 1996 r., Rioux v. Coulombe, [1998] 19 Estates and Trust Reports (2d) 201.

12 N. Kasirer, From Written Record to Memory in the Law of Wills, Ottawa Law Review 1997-1998, No 29, p. 43.

13 Ibidem, p. 61.

14 "I, Malcom Scott MacDonald, ID 5609065240106, do hereby declare that my last will and testament can be found on my PC at IBM under directory C:/windows/mystuff/mywill/personal".

15 MacDonald v. The Master, [2002] South African Law Reports 64.

16 M.C. Wood-Bodley, MacDonald v. The Master: Computer Files and the "Rescue" Provision of the Wills Act, South African Law Journal 2004, No 121, p. 34 et seq.

17 S. Snail, N. Hall, Electronic Wills in South Africa, Digital Evidence and Electronic Signature Law Review 2010, No. 7, p. 70. 
the intent to leave his last will exactly in that manner, and that the contents of the will on the hard disc complied with the declarations he made towards them. Analysing the facts of the case in the light of Article 9 of the Australian Wills Act 1997, the court decided that for the validity of the will and the related grant of probate it is necessary that three conditions are fulfilled: 1) there must be a document; 2) the document must comprise the will of the testator; 3 ) the testator must be willing to dispose of his property at the moment of drawing up the will. In the opinion of the court, each of the conditions was fulfilled in the considered case. Firstly, the file was recorded on a hard disc and might be displayed and duplicated, which gave it the attribute of a document. Secondly, the file included transparent and precise disposition with regard to the testator's property. Thirdly, the testator was willing to make the disposition at the moment of preparing the file. Therefore, on the computer printout of the will, despite the absence of the testator's signature, the grant of probate was given for the execution of the last will of the testator ${ }^{18}$. In some other Australian adjudication made nearly a decade later, the Supreme Court of the State of Queensland decided on 19 August 2011 that a file drawn up in Microsoft Word editor software, entitled "This is the last will and testament of Karen Lee Mahlo.docx", and recorded on the computer disc, many times sent between the testator and her partner through electronic mail, could be considered a valid will as to the principle, providing that the testator was willing to make the disposition at the moment of drawing it up. The court referred to the provisions of Article 18 of the Succession Act 1981, reading that for the validity of the will and granting of the probate a document must exist which, in the intent of the author, was supposed to be their last will. In that specific case the doubt referred not to the unacceptability of the electronic form of the will but to the willingness of the testator to dispose of her property ${ }^{19}$. The court found out that before her death the testator had prepared other wills signed by her personally, which in the opinion of the court signified that she was aware of the need of signing the disposition for the validity of the will. Although the very electronic form of a will would not contribute to its invalidity, as the court indicated that in other circumstances they would have accepted the validity of such disposition, yet upon confronting the will with the facts of the case, namely that other wills had been prepared in writing, as confirmed by the witnesses who had been told by the testator only about a written will, the court decided that the file left might have been only a draft of the will, without the intent of the testator to dispose of her property ${ }^{20}$.

18 Trethewey, [2002] Victoria Supreme Court 83.

19 B. Cannon, Is an Electronic Will a Will?, Australian Estate Law Today of 16 February 2012, p. 1 et seq.

20 Mahlo v Hehir, [2011] QueenslandSupreme Court 243. 
Also in Australia, quite recently (in 2013), two cases were considered by the Supreme Court of the State of Queensland with regard to the dispositions upon death made in electronic form but recorded otherwise. The first of the cases referred to an audio-video recording on a $\mathrm{DVD}^{21}$. As regards the facts of the case, the court decided that the DVD recording expressed the last will of the testator, which resulted first of all from the note made on the disc and from the very contents of the declaration recorded by the testator in that manner. In such circumstances, in the judgement of 27 November 2013, the court considered that such method of disposition fulfilled the requirements of Article 18 of the Succession Act 1981, as the DVD with the recording might be treated as a document being the carrier of the last will of the testator. Further, in the other case considered by the court, the testator made a note on his iPhone, entitled "This is my last will". Shortly afterwards, the testator committed a suicide, and the person named in the contents of the iPhone note as the executor of the will applied to the court for confirmation of the succession rights. In the judgement of 6 November 2013 the court decided that the application was valid, indicating that the wording of the electronic document and the contents thereof raised on doubts that the testator wanted to dispose of his property mortis causa in the manner specified in the note, and the electronic record in the "Notes" software of the iPhone was a document within the meaning of Article 18 of the Succession Act $1981^{22}$.

The international doctrine, commenting on the above Australian judgements emphasised, among other things, the modern trend in the interpretation of the succession law by the Australian courts ${ }^{23}$, and that in the era of smartphones or other electronic media, a growing number of informal dispositions upon death should be expected ${ }^{24}$, which had already been perceived by the Australian system. The assessment of the judgements was basically uniformly positive ${ }^{25}$, with the innovative way of thinking of the court and its willingness to view the established legal principles from another perspective in the new technological reality praised. It has also been suggested that in the future, the succession law provisions could follow that way ${ }^{26}$.

21 Mellino v. Wnuk, [2013] Queensland Supreme Court 336.

22 Queensland Supreme Court judgement of 6 Novemner 2013, Re: Yu, Queensland Law Reporter 2013, No. 48, p. 6-7.

23 Cf. L. Gordon, Wills - The Age of the Digital Will, Trust \& Private Client of 17 August 2015., p. 1.

24 See, for example, a note from a UK law firm addressed to its clients: Clever, Fulton, Rankin, A Legally Valid iPhone Will, http://www.cfrlaw.co.uk/site/wpcontent/uploads/2014/02/a-legally-valid-iphone-will.pdf.

25 B. Nillson, Can a Will Be Made On an iPhone, Lexology of 26 February 2014, p. 1.

26 Ch. Young, Y. O'Byrne, Dawn of the iPhone Will, STEP Journal 2014, p. 45. 
The innovativeness of the Australian solutions may be supported by other examples ${ }^{27}$. One of them is the judgement of the Supreme Court of the State of Victoria of 20 September 2013, in which a will made in an audiovideo format with the use of a Web camera was considered valid ${ }^{28}$. The examples of modern interpretations of the succession law standards originating from the Australian jurisdiction have created, as it may be expected, the grounds for some judgements in the succession cases of other legal systems. Although a will made with the use of modern technologies in breach of the regulations applicable to the form has not always been accepted, it has changed the perception of the traditional instruments of the succession law.

This may be confirmed with the judgements in cases in which the testators made their last will declarations with the use of the new technology, in breach of the binding regulations applicable to the form of a will, as made by the American courts, which also includes cases in which the courts refused to accept the validity of the will and grant of probate. For example, in one of the cases the testator availed of a tool popular in the USA for preparing documents of legal nature on-line, namely through the Legalzoom site. As regards the facts of the case, it was determined that the testator filled in a complicated form available on the Web, determining precisely the contents of her last will upon death, whereas the site sent her a paper version of the will before she got ill. The testator failed to sign the will at that time. Later she was admitted to a hospital where she requested the delivery of the will, and she obtained it, but she still failed to sign it being wrongly convinced that the signature must be put in the presence of a notary public. Before the notary public arrived at the hospital, the testator lost consciousness and died within a few days. The court of higher instance of the State of Connecticut in its judgement of 17 May 2013 decided that it was not possible to accept a will prepared in that manner to be valid, as it contradicted the requirements of the Statute of Wills of the State of Connecticut. Accordingly to the contents of $\S$ $45 \mathrm{a}-251$ of the Statute, the will must be made in writing and signed by the testator and the witnesses. The local law does not accept any solutions based on the substantial compliance doctrine, which would allow the validity of the disposition upon death. In the opinion of the court, the alternative techniques of preparing wills, even if desirable, had to be approved by the legislator. The then current state of affairs did not allow for another judgement in the said case. If a person wanted to make a will, then, in the opinion of the court, they had to do it in the way specified in the Statute ${ }^{29}$.

27 R. Kako, Wills and Estates: Informal Wills and Smartphones, Law Society Journal 2014, No. 4 , p. 42 et seq.

28 Estate of Sheron Jude Ladduhetti, unpublished judgement.

29 Litevich v. Probate Court, 2013 West Law Nr 2945055. 
In another case which was also held in 2013 before a court in the State of Ohio, the problem of drawing up and signing a will on a tablet was considered. The will of the testator was written with a pen on a tablet of one of the disposition witnesses, whereas the testator signed such electronic document in the presence of the witnesses, and then the witnesses put their signatures thereon. After the death of the testator the will was printed and submitted to the grant of probate procedure ${ }^{30}$. In accordance with Article 2107.03 of the Ohio Revised Code, a will other than oral, required a written form in order to be valid, handwritten or typed, the signature of the testator and the signatures of the witnesses present at the moment of making the disposition. In the opinion of the court, a verification was required whether the document had a written form and was signed as in the aforementioned standard, and whether there was sufficient evidence that the document was the disposition of the testator upon death. Analysing the case in that regard, the court indicated that, firstly, a document made on a tablet fulfilled the criteria of a written form, as no regulation required that the handwriting was recorded in any specific manner, so recording the handwriting on a tablet was allowed. Secondly, the court confirmed that the electronic document reflected the graphic form of signature, so might be considered to fulfil the aforesaid requirements. Despite the doubts regarding the absence of an attestation clause by the witnesses, namely a confirmation that the respective document was the last will of the testator ${ }^{31}$, the court considered that in the said case they dealt with a will, in relation to the application of the standard resulting from Article 2107.24 of the Ohio Revised Coe, based on the substantial compliance doctrine. In the opinion of the court, there was transparent and convincing evidence in this case that the document which did not fulfil all of the formal requirements, might form basis for coming into inheritance ${ }^{32}$.

The judgement brought about an avalanche of comments, both in media and in the doctrine. The innovative concept of the court was emphasised, among other things ${ }^{33}$, as well as the need to change the succession law in consideration of new technologies ${ }^{34}$, missing regulations applicable to

30 Estate of Javier Castro, Quinnipac Probate Law Journal 2014, No. 4, p. 412.

31 This type of clause is a frequent formal requirement of the will used by legislators in common law countries. See: R. Kerridge, Parry and Kerridge: The Law of Succession, London 2016, p. 53.

32 Cf. Justification of the judgment in the case: Estate of Javier Castro, http://www.lsslawyers.com/.

33 A. La Ratta, M.O. Dibble, What's in a Name? Writings Intended as Wills, Probate \& Property 2014, No. 3, p. 47.

34 B. Dicken, Judge Rules That a Will Written and Signed on Tablet is Legal, The Chronicle of 25 June 2013, http://www.chroniclet.com/; G. Smith, Ohio Judge Rules Electronic Will Written on Tablet is Valid, Berk Law Group of 12 November 2013, http://berklawgroup.com/. 
electronic wills ${ }^{35}$, the necessity of updating the succession law to be compliant with the modern times ${ }^{36}$, or the need for flexibility in applying laws. Even the judge making a decision in that case, requested for comments by the media, indicated that the state legislature should update the laws, as there was going to a growing number of such cases in the future ${ }^{37}$. Basically, the view must be shared, particularly because today's reality involves actually more and more electronics, compared to the previous years, and the first effects of that may also be seen in the succession law, where the particular testators have tried to avail of the instruments known to them in the inter vivos legal relations for the mortis causa purposes.

\section{Rethinking needed}

The need of revising the views on applying the traditional concepts of the succession law with regard to inheritance based on a will has already been raised in other places and other countries. It has been frequently suggested that the contemporary succession reality differs significantly from the times when most of the legal acts were drawn up in that regard, which also refers to the form of a will. For example, it has been mentioned in Poland that the existing forms of will raise various doubts, are outdated and fail to take into account the civilisation and technology development ${ }^{38}$. Such views have also been presented in other European countries, just to mention Germany, Switzerland, the Netherlands, or the UK. The arguments must be basically supported. The succession law requires a reform in that regard ${ }^{39}$. The matter is up-to-date on the background of the particular European succession law systems, the more so because some of the adjudication problems have been encountered in practice, although they may not be found in the published judgements. Both on the legal consulting sites and in the doctrine, there have been found signals of the existence of certain difficulties in using technology for the purpose of succession law. For example, there have appeared questions about the recording of the last will on an audio cassette, recording of voice as the evidence of making an oral will, the possibility of preparing an electronic will (a file in a text editor), or the possibility of using an electronic signature in making a will. All of the problems, in the light of the currently binding

35 J.A. McKinsey, D.D. Burke, Carper's Understanding the Law, Stamford 2015, p. 666.

36 D. Caroll, Validity of an Electronic Will, Insurance \& Investment Journal of 28 January 2014, http://insurance-journal.ca/.

37 As indicated by the media statements: K.B. Gee, Electronic Wills At Our Fingertips. Should They Be Admited to Probate?, Cleveland Metropolitan Bar Journal 2013, No. 12, p. 20-21.

38 Cf. A. Pabin, Testament jako akt sformalizowany - uwagi w sprawie przyszłego ksztattu regulacji dotyczacych formy rozrzadzeń testamentowych, Studia Prawnicze 2016, No. 1, p. 119.

39 M. Zalucki, Perspektywy rekodyfikacji polskiego prawa spadkowego, [in:] 50 lat kodeksu cywilnego. Perspektywy rekodyfikacji, ed. M. Załucki, Warszawa 2015, p. 355 et seq. 
regulations with regard to the form of a will, would probably be handled negatively for the testator in the particular European legal systems ${ }^{40}$. So if a testator with the habitual place of residence in Poland decided to make a will in a modern way, the effort would probably be wasted in arriving at the intended effect. Meanwhile, it seems that the necessity of adjusting the regulations regarding the form of a will to the current requirements is unavoidable.

\section{Conclusion}

Designing the succession law standards, the modern legislator must do it such as to reflect the needs of the society in the legal provisions. One of the needs seems to be the possibility of using the opportunities created by new technologies in disposing property mortis causa. In order to ensure the execution of the testator's will upon death, the legislators must search for such instruments which may become an alternative to the solutions originating in the Roman times. The traditional forms of a will should not, therefore, be the only forms of disposing of property upon death. It is high time to start a discussion on adjusting the succession law instruments to the current times. New technologies are also new challenges for inheritance law. The requirement to draw up a will by hand, or any other traditional way, which is known to most of today's legal systems, cannot now be understood in the same way as when the traditional form of the will was created. New formats for making declarations of will, based on technical instruments, are, as one might think, also tools ready to be used in succession law. The reflection of the testator's last will should still be the most important value of the inheritance law, although the instruments that are adequate for the times in which the testator lives should also serve to reflect this will. Therefore, the law of succession should be adapted to modern times.

\section{References:}

1. Cannon B., Is an Electronic Will a Will?, Australian Estate Law Today of 16 February 2012.

2. Caroll D., Validity of an Electronic Will, Insurance \& Investment Journal of 28 January 2014

3. Dicken B., Judge Rules That a Will Written and Signed on Tablet is Legal, The Chronicle of 25 June 2013

4. Gee K.B., Electronic Wills At Our Fingertips. Should They Be Admited to Probate?, Cleveland Metropolitan Bar Journal 2013, No. 12.

40 Without a detailed analysis of the facts, it is difficult to reach categorical conclusions, after all, it is possible to use even the instrument of conversion of dispositions of property upon death. 
5. Gordon L., Wills - The Age of the Digital Will, Trust \& Private Client of 17 August 2015.

6. Kako R., Wills and Estates: Informal Wills and Smartphones, Law Society Journal 2014, No. 4.

7. Kasirer N., From Written Record to Memory in the Law of Wills, Ottawa Law Review 1997-1998, No. 29.

8. Kerridge R., Parry and Kerridge: The Law of Succession, London 2016.

9. La Ratta A., Dibble M.O., What's in a Name? Writings Intended as Wills, Probate \& Property 2014, No. 3

10. Nass H.E., We Can't Stop Loving You, Trusts \& Estates 2005, issue 8.

11. Nillson B., Can a Will Be Made On an iPhone, Lexology of 26 February 2014.

12. Pabin A., Testament jako akt sformalizowany - uwagi w sprawie przyszłego kształtu regulacji dotyczacych formy rozrzadzeń testamentowych, Studia Prawnicze 2016, No. 1.

13. Ponath G., Die Beschränkungen der Testierfreiheit durch das Testamentsrecht, Frankfurt-Mannheim 2006.

14. Pound R., The Role of the Will in Law, Harvard Law Review 1954, issue 1 .

15. Smith G., Ohio Judge Rules Electronic Will Written on Tablet is Valid, Berk Law Group of 12 November 20131 McKinsey M.O., Burke D.D., Carper's Understanding the Law, Stamford 2015.

16. Snail S., Hall N., Electronic Wills in South Africa, Digital Evidence and Electronic Signature Law Review 2010, No. 7.

17. Świrgoń-Skok R., Swoboda dysponowania majątkiem na wypadek śmierci w ujęciu historycznoprawnym, [in:] Rozprawy cywilistyczne. Ksiega pamiatkowa dedykowana Profesorowi Edwardowi Drozdowi, eds. M. Pecyna, J. Pisuliński, M. Podrecka, Warszawa 2013.

18. Wood-Bodley M.C., MacDonald v. The Master: Computer Files and the "Rescue" Provision of the Wills Act, South African Law Journal 2004, No. 121.

19. Young Ch., O'Byrne Y., Dawn of the iPhone Will, STEP Journal 2014.

20. Załucki M., Forma testamentu w perspektywie rekodyfikacji polskiego prawa spadkowego. Czas na rewolucję?, Państwo i Prawo 2017, issue 3.

21. Załucki M., Perspektywy rekodyfikacji polskiego prawa spadkowego, [in:] 50 lat kodeksu cywilnego. Perspektywy rekodyfikacji, ed. M. Załucki, Warszawa 2015.

22. Zalucki M., Videotestament. Prawo spadkowe wobec nowych technologii, Warszawa 2018. 
23. Zimmermann R., Testamentsformen: »Willkür« oder Ausdruck einer Rechtskultur?, Rabels Zeitschrift für ausländisches und internationales Privatrecht 2012. 